\title{
THE SUPPLY AND DEMAND SIDES OF JUDICIAL POLICY-MAKING (OR, WHY BE SO POSITIVE ABOUT THE JUDICIALIZATION OF POLITICS?)
}

\author{
CORNELl W. ClAYTON*
}

\begin{abstract}
The actual art of governing under our Constitution does not and cannot conform to judicial definitions of the power of any of its branches based on isolated clauses or even single Articles torn from context. While the Constitution diffuses power the better to secure liberty, it also contemplates that practice will integrate the dispersed powers into a workable government. It enjoins upon its branches separateness but interdependence, autonomy but reciprocity.... We may begin [any constitutional analysis] by distinguishing roughly the legal consequences of this factor of relativity.
\end{abstract}

Justice Robert H. Jackson ${ }^{1}$

Theoretically, Article I of the Constitution places the legislative power in Congress or, more accurately, jointly in Congress and in the Presidency, acting in accordance with the formalities of bicamerality and presentment. When this body-which we shall call the constitutional legislature - is capable of action, it will retain control of legislative authority.... Courts and agencies are capable of independent or autonomous action where the constitutional legislature is too fragmented to react. In such circumstances, lawmaking will tend to migrate to those bodies that are capable of decisive action. In these conditions we see the development of such familiar entities as the "runaway" bureaucracy and the activist courts.

Professor John Ferejohn ${ }^{2}$

\section{INTRODUCTION}

Explanations of judicial behavior that draw upon positive institutional theory have gained growing prominence within both the political science and the legal academies. ${ }^{3}$ Within the latter, Professor John Ferejohn has been a leader

Copyright (C) 2002 by Cornell W. Clayton

This article is also available at http//www.law.duke.edu/journals/65LCPClayton.

* Associate Professor of Political Science, Washington State University.

1. Youngstown Sheet \& Tube Co. v. Sawyer, 343 U.S. 579, 635 (1952) (Jackson, J., concurring).

2. John Ferejohn, Judicializing Politics, Politicizing Law, 65 LAW \& CONTEMP. ProBs. 41, 63 (2002) (citations omitted).

3. The political science literature is extensive and dates back at least to Walter F. Murphy's classic ELEMENTS OF JUDICIAL STRATEGY (1964). More recent works that adopt a positive theoretical approach to judicial decision-making include: LEE EPSTEIN \& JACK KNIGHT, THE CHOICES JUSTICES MAKe (1998); Forrest Maltzman ET Al., Crafting LAW ON THE Supreme Court: The Collegial Game (2000) [hereinafter Maltzman et Al., Crafting LaW on the Supreme COURT]; Paul Brace \& Melinda Gann Hall, Neo-Institutionalism and Dissent in State Supreme Courts, 52 J. Pol. 54 (1990); Melinda Gann Hall \& Paul Brace, Toward an Integrated Model of Judicial Voting Behavior, 20 AM. POL. Q. 147 (1992); Jack Knight \& Lee Epstein, On the Struggle for Judicial Suprem- 
in developing the neo-institutional approach to the study of the law and the courts. ${ }^{4}$ His work has been particularly important in developing so-called "separation-of-powers" models of judicial behavior." These "separation-ofpowers" models seek to explain judicial decisions by reference to exogenous constraints, such as the powers of Congress and the President to control federal courts, rather than by reference to endogenous constraints, such as the collegial nature of decision-making on certain appellate courts and the need to maintain a majority and avoid dissension. ${ }^{6}$ Ferejohn's contribution to this symposium further develops this line of inquiry by outlining the possibility of a positive

acy, 30 LAW \& SOC. REV. 87 (1996). For an excellent discussion on the use of positive institutional theory in past and present political science scholarship concerning courts, see Forrest Maltzman et al., Strategy and Judicial Choice: New Institutionalist Approaches to Supreme Court Decision-Making, in Supreme Court Decision-MAKING: New Institutionalist ApPROACHES 43 (Cornell W. Clayton \& Howard Gillman eds., 1999) [hereinafter Maltzman et al., Strategy and Judicial Choice].

Legal academic literature drawing upon the insight of positive institutional theory has also become extensive in recent years. See, e.g., Jenna Bednar \& William N. Eskridge, Jr., Steadying the Court's "Unsteady Path": A Theory of Judicial Enforcement of Federalism, 68 S. CAL. L. REV. 1447 (1995); John M. de Figueiredo \& Emerson H. Tiller, Congressional Control of the Courts: A Theoretical and Empirical Analysis of Expansion of the Federal Judiciary, 39 J. L. \& ECON. 435 (1996); William N. Eskridge, Jr., Civil Rights Legislation in the 1990s: Reneging on History? Playing the Court/Congress/President Civil Rights Game, 79 CAL. L. REV. 613 (1991); William N. Eskridge, Jr., The Judicial Review Game, 88 Nw. U. L. REV. 382 (1993); William N. Eskridge, Jr., Overriding Supreme Court Statutory Interpretation Decisions, 101 YALE L.J. 331 (1991) [hereinafter Eskridge, Overriding Supreme Court Statutory Interpretation Decisions]; William N. Eskridge, Jr. \& Philip P. Frickey, Foreword: Law as Equilibrium, 108 HARV. L. REV. 26 (1994); Robert W. Hahn \& Roger G. Noll, Barriers to Implementing Tradable Air Pollution Permits: Problems of Regulatory Interactions, 1 YALE J. ON REg. 63 (1983); McNollgast, Politics and the Courts: A Positive Theory of Judicial Doctrine and the Rule of Law, 68 S. CAL. L. REV. 1631 (1995); McNollgast, Positive Canons: The Role of Legislative Bargains in Statutory Interpretation, 80 GEO. L.J. 705 (1992); William H. Riker \& Barry R. Weingast, Constitutional Regulation of Legislative Choice: The Political Consequences of Judicial Deference to Legislatures, 74 VA. L. REV. 373 (1988); Daniel B. Rodriguez, The Positive Political Dimensions of Regulatory Reform, 72 WASH. U. L.Q. 1 (1994); Pablo T. Spiller \& Emerson H. Tiller, Decision Costs and the Strategic Design of Administrative Process and Judicial Review, 26 J. LEGAL STUD. 347 (1997); Pablo T. Spiller \& Emerson H. Tiller, Invitations To Override: Congressional Reversals of Supreme Court Decisions, 16 INT'L REV. L. \& ECON. 503 (1996); Emerson H. Tiller, Putting Politics into the Positive Theory of Federalism: A Comment on Bednar and Eskridge, 68 S. CAL. L. REV. 1493 (1995).

4. See, e.g., William N. Eskridge, Jr. \& John Ferejohn, Virtual Logrolling: How the Court, Congress, and the States Multiply Rights, 68 S. CAL. L. REV. 1545 (1995) [hereinafter Eskridge \& Ferejohn, Virtual Logrolling]; William N. Eskridge, Jr. \& John Ferejohn, The Article I, Section 7 Game, 80 GEO. L.J. 523 (1992) [hereinafter Eskridge \& Ferejohn, The Article I, Section 7 Game]; John Ferejohn, Law, Legislation, and Positive Political Theory, in MODERn POLITICAL ECONOMY 191 (Jeffrey S. Banks \& Eric A. Hanushek eds., 1995) [hereinafter Ferejohn, Law, Legislation, and Positive Political Theory]; John Ferejohn \& Barry R. Weingast, Limitation of Statutes: Strategic Statutory Interpretation, 80 GEO. L.J 565 (1992) [hereinafter Ferejohn \& Weingast, Limitation of Statutes]; John A. Ferejohn \& Barry R. Weingast, A Positive Theory of Statutory Interpretation, 12 INT'L REV. L. \& ECON. 263 (1992); John Ferejohn \& Charles Shipan, Congressional Influences on Bureaucracy, 6 J. L. ECON. \& ORG. 1 (1990) [hereinafter Ferejohn \& Shipan, Congressional Influences on Bureaucracy].

5. See also Eskridge \& Ferejohn, The Article I, Section 7 Game, supra note 4; Eskridge \& Ferejohn, Virtual Logrolling, supra note 4; Ferejohn, Law, Legislation, and Positive Political Theory, supra note 4; Ferejohn \& Shipan, Congressional Influences on Bureaucracy, supra note 4; Ferejohn \& Weingast, A Positive Theory of Statutory Interpertation, supra note 4; Ferejohn \& Weingast, Limitation of Statutes, supra note 4.

6. For a discussion of the difference between exogenous and endogenous variants of neoinstitutional approaches, see Maltzman et al., Strategy and Judicial Choice, supra note 3. Perhaps the best example of the latter approach is MALTZMAN ET AL., CRAFTING LAW ON THE SUPREME COURT, supra note 3 . 
model of the judicialization of politics, and by suggesting institutional reforms that would reduce the level of the judicialization of politics in the United States.

Although Professor Ferejohn's argument is still in its preliminary form, and some key features remain undeveloped, his argument nevertheless suggests important ways to think about both the relationship between law and politics in the United States and what should be done about the growing political role of the federal courts in U.S. democracy. This article begins by examining the central elements of Professor Ferejohn's argument. Part III specifically focuses on the relationship between the model of the judicialization of politics and Ferejohn's normative argument and proposals for reform. Part IV concludes by raising a few more general concerns about positivist models of judicial behavior.

II

\section{FEREJOHN ON THE JUDICIALIZATION OF POLITICS}

Professor Ferejohn's essay draws together several complex and nuanced lines of analysis. Therefore, I begin by outlining the four key arguments that he makes. First, Professor Ferejohn recasts the debates about the relationship between law and politics in institutional terms. In doing so, Ferejohn presents the relationship between law and politics as a debate about the proper institutional location of the legislative function-the power to make binding, prospective norms and rules. ${ }^{7}$ This approach draws from the constitutional theory of John Locke, who argued that, of the two analytically distinct functions of governments, legislating was the "sovereign" political power, while executing (including both ministerial and judicial functions) was a secondary, subordinate power: "There can be but one supreme power, which is the legislative, to which all the rest are and must be subordinate." Thus, for Locke, the crucial constitutional question was where to locate the legislative power institutionally. The answer to his question came in the form of the English theory of "mixed government." Under this approach, legislative power was dispersed among different institutions - the Crown, the House of Lords, and the House of Commons. Each institution had some role in making law, or legislating, and each represented different estates or classes of citizens (royals, landed aristocrats, and commoners) as well as different constitutional principles of government (monarchical, oligarchical, and democratic). ${ }^{9}$

7. Ferejohn, supra note 2, at 3, 8-11.

8. JOHN LOCKE, SECOND TREATISE OF CIVIL GOVERnMENT, ch. xiii, para. 149 (1690). Locke held that the judicial function was in fact a part of the executive, as judges and ministers both were charged with applying the law, as that law was made elsewhere. The only difference was that ministers applied the law generally, while judges applied it in particular cases. While this called forth the need for norms and institutional protections of judicial impartiality, it did not imply judicial independence or the idea that judges should be thought of as performing an analytically distinct function of government. For an excellent discussion of the Lockean conception of the separation of powers and how it differs from both Montesquieu's and Madison's conceptions, see GEOFFREY MARSHALL, CONSTITUTIONAL THEORY 97-124 (1971).

9. MARSHALL, supra note 8. 
By contrast, the U.S. Constitution follows the institutional theory of Montesquieu-concentrating or segregating different governmental functions (legislative, executive, and judicial) in separate departments or branches (the Congress, the President, and the courts).$^{10}$ Within this system, the legislative power is traditionally associated with the Congress or, in Professor Ferejohn's terms, the "constitutional legislature"- the Congress and the President acting in accordance with the formalities of bicamerality and presentment. ${ }^{11}$

The legislative power can nevertheless relocate itself to other institutions, such as the courts and the executive agencies. James Madison and other founding fathers did not envision a complete separation of functions or a hermetic sealing-off of powers, but rather provided for some degree of sharing between branches to produce an equilibrium in which government controls itself-the checks and balances system. ${ }^{12}$ Madison asserted that separation of powers did not mean that the "departments ought to have no partial agency in, or no control over, the acts of each other." Rather, Madison believed that separation of powers in the U.S. insured that the "whole power of one department (should not be) exercised by the same hands which possess the whole power of another department ...."13

What Professor Ferejohn wishes to draw our attention to, however, is that the degree to which the legislative function is shared with other departments and agencies, including the courts, fluctuates depending upon needs and circumstances. Therefore, normative analysis of judicial legislating must always be subject to a "contextual inquiry" examining the actions and relations of other departments and agencies. ${ }^{14}$ This is an important point that should not be too quickly brushed over. The question whether a particular level of judicial legislating or judicialization of politics is constitutionally appropriate is therefore contingent on, or, as Justice Jackson said in his concurring opinion in Youngstown Sheet \& Tube Co. v. Sawyer, "relative" to, the broader institutional context within which it takes place. ${ }^{15}$ Thus, as a normative matter, whether courts are acting appropriately, or whether they are usurping constitutional power when intervening in politics, turns in large part on the actions of other institutional actors, especially Congress and the President.

10. As Madison noted, at the time of the framing Montesquieu was "the oracle who [was] always consulted and cited on this [the theory of separation of powers] subject." THE FEDERALIST NO. 47, at 301 (James Madison) (Clinton Rossiter ed., 1961). For a thorough treatment of the history of the theory of separation of powers, with special emphasis on the U.S. theory of separation of powers and its heritage from Locke through Montesquieu through Madison, see generally M.J.C. VILE, CONSTITUTIONALISM AND THE SEPARATION OF POWERS (1967).

11. Ferejohn, supra note 2, at 14-15.

12. Madison, supra note 10.

13. Id. at 302-03.

14. Ferejohn, supra note 2, at 14.

15. 343 U.S. 579, 634-54 (1952) (Jackson, J., concurring). Jackson makes this point in reference to analyzing presidential powers vis-à-vis Congress. Since the presidency is a co-equal and co-dependent branch, however, his argument would also hold true for any analysis of the judicial branch. 
A second argument is closely related. That is, whether and when courts assume legislative power also depends on "structural-political factors" either permitting or constraining judicial independence from the elected branches. This is not independence in the sense of impartial decision-making in individual cases, but independence from the broad political direction of the elected branches. Thus, the degree to which politics becomes judicialized is not dependent on the individual ideological aspirations of judges (or what political scientists refer to as "judicial attitudes") but on institutional relationships between the branches. ${ }^{16}$ Here, Professor Ferejohn separates questions about the scope of judicial policy-making from questions about its direction. According to Ferejohn, the latter is dependent on the views or attitudes of individual judges, while the former is shaped by the institutional factors permitting or prohibiting judicial independence. Moreover, these institutional factors are possible to model in a positive or a formal way.

For reasons I discuss below, the most important factor affecting judicial independence in the United States is the degree to which the constitutional legislature is either unified or disunified. Given this, a Ferejohnian model of the judicialization of politics presumably would focus attention on the degree of ideological or partisan cohesion between the two houses of Congress and between Congress and the White House. During periods of electoral dealignment and divided government - the norm in the United States since the 1960s - one would expect to find a more active, independent policy-making role for the federal courts. Conversely, during periods of strong, unified party control, as existed during the late 1930s and 1940s, one would expect to find a more restrained policy-making role for the judiciary. During these periods, courts would mostly operate in the shadows of the elected branches.

Third, Professor Ferejohn argues that the structural-regime features that are favorable to the judiciary assuming legislative powers generally are also favorable to judicial control of the democratic process. That is to say, those factors that allow for an independent policy-making role for the courts will also tend to

16. A major, perhaps dominant, line of political science research on judicial decision-making has focused on the individual attitudes of judges. According to the so-called "attitudinal model," Supreme Court justices in particular are unconstrained either by legal factors (legal doctrines and professional norms such as stare decisis) or by strategic institutional concerns (such as fear of congressional overrides) when making decisions. As such, the justices are free to vote their own policy preferences when deciding cases, thus making the broader political role of the Court entirely dependent on the ideological attitudes of its individual members at any given time. The classic and most thorough treatment of the "attitudinal model" of Supreme Court behavior is JEFFREY A. SEgAL \& HAROLD J. SPAETH, ThE Supreme Court AND the AtTitudinal Model (1993). See also Timothy M. Hagel \& Harold J. Spaeth, The Emergence of a New Ideology: The Business Decisions of the Burger Court, 54 J. POL. 12034 (1992); Jeffrey A. Segal et al., Ideological Values and the Votes of U.S. Supreme Court Justices Revisited, 57 J. POL. 812-23 (1995); Jeffrey A. Segal \& Albert D. Cover, Ideological Values and the Votes of U.S. Supreme Court Justices, 83 AM. POL. SCI. REV. 557-65 (1989). Despite the attitudinal model's success in predicting case outcomes in narrowly defined areas of law, it has been widely criticized by both rational choice and historical institutional scholars. See, e.g., Richard A. Brisbin, Jr., Slaying the Dragon: Segal, Spaeth and the Function of Law in Supreme Court Decision-Making, 40 AM. J. POL. SCI. 1004-17 (1996); Symposium, The Supreme Court and the Attitudinal Model, 4 LAW \& CT. NEWSL. 2 (1994). 
lead the courts to be more active in regulating such things as apportionment, access to the ballot box, and the decision-making processes in Congress and the executive. Moreover, these judicial interventions will usually require the processes of the elected branches to conform more closely to the procedures and decision-making processes of the courts.

The court can make rules in this area under the same circumstances in which it can make rules generally, but in this area uniquely, the court is not merely making rulesit is forcing the legislature to alter internal procedures and processes; it is forced to make legislative decisions more like judicial ones. ${ }^{17}$

The fact that there is no distinction between the structural-institutional features permitting judicial policy-making generally, and judicialization of the political-electoral process itself, explains why the Supreme Court has become less reluctant to enter deeper and deeper into what Justice Frankfurter called the "political thicket." Since the 1960s, the U.S. government has been marked by electoral de-alignment and divided control of the constitutional legislature. ${ }^{19}$ It should therefore not be surprising that the Supreme Court's role in the political system has grown relatively unchecked, leading up to its astonishing assertion of judicial power last year in Bush v. Gore. ${ }^{20}$

Fourth, Professor Ferejohn outlines certain normative implications of his argument. Courts, he suggests, are institutionally well-suited to make some types of policy - such as legislating in areas that require special attention to the rights of minorities or in areas where a "deliberative process" is desirable. Courts, however, are ill-suited for making other types of policy-such as decisions about farm subsidies or the best ways to control air pollution. These latter types of policy decisions-because of the special technical expertise, political give-and-take, and bargaining they require-are more amenable to the decision-making processes of the legislatures and administrative agencies where "appropriate outcomes" are thought to be definable in terms of democratic preferences. $^{21}$

Finally, Professor Ferejohn argues that, when courts expand their legislative activity into areas where they are institutionally ill-suited, the solution is not simply to appoint a "different" or the "right" type of judge. Indeed, recent efforts to rein in an activist judiciary by appointing "strict constructionists," "judicial restraintists," or "constitutional originalists" have demonstrably failed. ${ }^{22}$

17. Ferejohn, supra note 2, at 62-63.

18. Colegrove v. Green, 328 U.S. 549, 556 (1946).

19. One or both houses of Congress have been controlled by a different political party than the White House for all but six years since 1968.

20. 531 U.S. 98 (2000). In his contribution to this symposium, Professor Levinson offers precisely this type of "strategic choice" explanation for how the Court came to its decision in Bush v. Gore. Sanford Levinson, Bush v. Gore and the French Revolution: A Tentative List of Some Early Lessons, 65 LAW \& CONTEMP. PROBS. 7 (2002).

21. Ferejohn, supra note 2, at 67-68.

22. For a general discussion of the institutional causes of the judicialization of politics and the failure of judicial appointment strategies aimed at curbing it since the 1960s, see CORNELL W. CLAYTON, The Politics of Justice: The AtTorney General AND the Making OF Legal PoliCy 120-71 
Rather, the solution lies in crafting institutional mechanisms that remove some judicial independence from the elected branches. Here, Professor Ferejohn suggests two specific reforms that would produce such an effect: (1) requiring a super-majority in the Senate for judicial appointments; and (2) limiting justices to a single nonrenewable term of office. ${ }^{23}$

III

\section{THE SUPPLY- AND DEMAND-SidE OF JUdiCIALIZING POLITICS}

By redirecting our attention away from the attitudes and political preferences of individual judges and toward the institutional causes and contexts of judicial behavior, Professor Ferejohn makes an important contribution to our understanding of the judicialization of politics generally. Nevertheless, there is much about these institutional contexts that may not be fully captured by the type of model that Professor Ferejohn proposes or that is adequately considered in his implicit and explicit normative arguments for institutional reform. I will begin by examining Professor Ferejohn's central empirical claim-that the political role of courts is dependent on relationships within and between the elected branches. More specifically, Ferejohn argues that unified control of the elected branches will tend to reduce judicial independence while divided control will tend to expand it.

The claim that the political role of courts is tied to structural features of the national governing coalition as a matter of historical description is incontrovertible. There now exists a very large body of empirical research in history and political science supporting the claim made more than a century ago by Finley Peter Dunne's fictional character Mr. Dooley, who told us that "th' Supreme Court follow th' iliction returns." ${ }^{24}$ Robert Dahl's classic 1957 article, The Supreme Court as a National Policy-Maker, clearly demonstrated that the Court rarely has strayed far, or for very long, from the concerted policy directions of the elected branches. ${ }^{25}$ More recent empirical research has gone much further, tying the political role of the courts to specific patterns of party politics, partisan electoral realignments, and unified or disunified control of national electoral institutions. $^{26}$

(1992) [hereinafter Clayton, Politics of Justice]. See also The Burger Court: The CounterREVOLUTION THAT WASN'T (Vincent Blasi ed., 1983).

23. Ferejohn, supra note 2, at 6,16.

24. Finlay Peter Dunne, On the Supreme Court's Decisions, in Mr. Dooley In PeACE AND WAR (1898), in DAVID M. O'BRIEN, STORM CENTER: THE SUPREME COURT IN AMERICAN POLITICS 361 (1996).

25. Robert Dahl, Decision-Making in a Democracy: The Supreme Court as a National PolicyMaker, 6 J. PUB. L. 279 (1957). For a similar argument see Martin Shapiro, Political Jurisprudence, 52 KY. L. J. 294 (1964).

26. The political science literature in this area is vast. Some particularly good examples include John B. GATES, THE SUPREME COURT AND PARTISAN REALIGNMENT: A MACRO- AND Microlevel Perspective (1992); William Lasser, The Limits of Judicial Power: The SuPREME COURT IN AMERICAN POLITICS (1988); David Adamany, The Supreme Court's Role in Critical Elections, in REALIGNMENT IN AMERICAN POLITICS 229 (Bruce A. Campbell \& Richard J. Trilling 
The fact that the courts' policy-making role is fundamentally tied to relationships within and between the elected branches should not be surprising. The judicial branch was constitutionally designed to be dependent on the elected branches in numerous ways-for the appointment and removal of its members, for its staffing, for its budgets, for the scope of its appellate jurisdiction, and, most importantly, for the enforcement of its decisions. In fact, these constitutional features of judicial dependency are what Alexander Hamilton referred to when he predicted that the courts would be the "least dangerous" branch. $^{27}$

Whoever attentively considers the different departments of power must perceive, that, in a government in which they are separated from each other, the judiciary, from the nature of its functions, will always be the least dangerous to the political rights of the Constitution; because it will be least in a capacity to annoy or injure them.... It may truly be said to have neither FORCE nor WILL but merely judgement; and must ultimately depend upon the aid of the executive even for the efficacy of its judgements. ${ }^{28}$

Unfortunately, little empirical research demonstrating the historical accuracy of Hamilton's prediction or Mr. Dooley's observation has made its way into legal scholarship. Instead, this literature has focused almost exclusively, and in some ways almost pathologically, on the normative aspects of the relationship between the courts and the elected branches-that is, whether judicial review is counter-majoritarian, and, if so, how it can be justified in a democracy. ${ }^{29}$ This debate and the various responses to it are well-known, and I will not recount them here. ${ }^{30}$ If, however, the empirical claim is true-if courts rarely deviate from the concerted and coherent policy direction of the electedgoverning coalition-then the normative debate becomes largely academic. ${ }^{31}$ In other words, if courts use their power to reinforce, rather than to thwart, the political agenda of the elected branches, then judicial policy-making may raise

eds., 1980); Paul Allen Beck, Communication-Critical Elections and the Supreme Court: Putting the Cart After the Horse, 70 AM. POL. SCI. REV. 930 (1976); Richard Funston, The Supreme Court and Critical Elections, 69 AM. PoL. SCI. REV. 795 (1975); John B. Gates, Partisan Realignment, Unconstitutional State Policies, and the U.S. Supreme Court, 1837-1964, 31 AM. J. POL. SCI. 259 (1987); John B. Gates, Supreme Court Voting and Realigning Issues: A Microlevel Analysis of Supreme Court PolicyMaking and Electoral Realignment, 13 SOC. SCI. HIST. 255 (1989); William Lasser, The Supreme Court in Periods of Critical Realignment, 47 J. POL. 1174 (1985).

27. THE FEDERALIST No. 78, at 465 (Alexander Hamilton) (Clinton Rossiter ed., 1961).

28. $I d$.

29. Alexander M. Bickel identified the "counter-majoritarian difficulty" as the central problem for U.S. constitutional theory some four decades ago in THE LEAST DANGEROUS BRANCH: THE SuPREME COURT AT THE BAR OF POLITICS 16-17 (1962). For an excellent discussion of the legal academy's preoccupation with this normative question, see Barry Friedman, The Counter-Majoritarian Problem and the Pathology of Constitutional Scholarship, 95 Nw. U. L. REV. 933 (2001).

30. Friedman, supra note 29.

31. I say largely, not entirely, because there remain interesting questions about the judicial role in softening democratic majoritarianism and fostering democratic deliberation and civic republicanism. See, e.g., CASs R. Sunstein, THE PARTIAL CONSTITUtion (1993). 
interesting questions about center-periphery relationships in government, but it does not pose problems for democracy per se. ${ }^{32}$

Now, if it is clear that the political role of the courts has historically reflected the broad structural makeup of, and shifts in, the electoral coalition of the national political regime, what are we to make of the implicit argument that certain features of the current political regime-electoral de-alignment and the semi-permanent structure of divided government-have altered this nexus? Courts are now more independent of the elected branches and have strayed too far into the electoral-legislative arena, because the elected branches are unable to respond to such incursions in a coherent, unified way. In short, the divided control of the elected branches has left courts free from fear of retaliation and court-curbing measures, such as those used during the 1930s to rein in an independent judiciary. As a result, other institutional remedies aimed at reducing judicial independence are necessary. ${ }^{33}$

Let me begin by saying that I agree with much of this argument; there is clearly a nexus between disunified control of the elected branches and the expanded policy-making role of the federal courts during the latter half of the twentieth century. ${ }^{34}$ Recasting this nexus in a slightly different way, however, may have important normative consequences. Professor Ferejohn is certainly right to draw insight from positive institutional theory (or strategic choice approaches to judicial decision-making) to emphasize how divided government increases judicial independence by reducing the ability of the elected branches to act in concert (thus reducing the fear judges have regarding retaliation or retribution for unpopular decisions). This is only part of the picture, however, and it captures only the supply-side of the judicialization of politics-courts will make policy when there are no barriers restraining them from doing so.

A complete explanation of how disunified control of the elected branches produces judicial legislation would have to account as well for the demand-side of judicial policy-making. As reactive institutions, courts must have policy disputes brought to them in the form of cases before they can make policy. The inability of the electoral political process to resolve important policy disputes during periods of divided government often pushes political mobilizations into other arenas: Social movements, interest groups, and elites in the elected branches begin to turn to courts and administrative agencies for policy goals

32. I claim no originality in making this point. Mark Graber, among many others, made this very argument several years ago. See Mark A. Graber, The Nonmajoritarian Difficulty: Legislative Deference to the Judiciary, 7 STUD. IN AM. POL. DEVELOPMENT 35 (1993).

33. Although this argument is not explicit in Professor Ferejohn's paper, it is implicit in his normative conclusions and suggestions for institutional reforms aimed at limiting the independence of courts. See Ferejohn, supra note 2, at 6. In any event, it is reasonable to conclude that, if unified control of the constitutional legislature monopolizes legislative power, then the converse would tend to disperse legislative power to other arenas, such as the courts. The longer the elected branches remained divided and disunified, the more legislative power would migrate. Thus, one would expect to have seen a particularly active and independent judiciary during the post-1960s period.

34. I make a similar argument in CLAYTON, POLITICS OF JUSTICE, supra note 22. 
that they cannot obtain from a disunified Constitutional Legislature. ${ }^{35}$ In this sense, courts are not unwelcome intruders into the democratic process, but invited (and perhaps necessary) release valves for democratic impulses that cannot be addressed through the ordinary legislative route. ${ }^{36}$

Once we begin to focus more attention on the demands for judicial intervention into the political system, the normative questions surrounding judicial policy-making become more complicated. Whether the shifting of policy-making into courts or administrative agencies is democratically desirable or undesirable consequently may have less to do with the decision-making processes of different institutions than with the substantive policy outcomes produced. Even if we assume that a clear analytic distinction can be made between institutional processes and policy outcomes, ${ }^{37}$ normative judgments about the appropriateness of policy-making by particular institutions may still force us to look beyond the simple question of which institutional processes are best suited for different types of policy questions. For example, while the Supreme Court's intrusion into the electoral arena to decide the outcome of a presidential election clearly raises serious normative concerns about the role of courts in a democracy, ${ }^{38}$ other examples where political mobilizations turned to courts may be less objectionable. The Supreme Court's early civil rights decisions, such as Shelley $v$. Kraemer $^{39}$ and Brown v. Board of Education, ${ }^{40}$ and its early reapportionment decisions in Baker v. Carr ${ }^{41}$ and Reynolds v. Simms, ${ }^{42}$ for example, may represent instances where democratic mobilizations were blocked by an electoral system that allowed a minority (Southern Democrats) to control Congress and thwart

35. This more interactive explanation of how disunified control of the elected branches since the 1960s has led to the judicialization of politics in the United States can be found in CLAYTON, POLITICS OF JUSTICE, supra note 22, at 120-71. See also BENJAMIN GINSBERG \& MARTIN SHEFTER, POLITICS BY OTHER MEANS: THE DECLINING IMPORTANCE OF ELECTIONS IN AMERICA (1990); Mark Silverstein \& Benjamin Ginsberg, The Supreme Court and the New Politics of Judicial Power, 102 POL. SCI. Q. 371 (1987).

36. See Clayton, Politics of Justice, supra note 22; Graber, supra note 32.

37. Here, I leave aside the question whether a conceptual distinction between democratic decisionmaking processes and substantive policy outcomes is one that can be maintained. It may be that such a distinction would run into similar problems raised by efforts to construct a purely process-based constitutional jurisprudence. See Laurence Tribe, The Puzzling Persistence of Process-Based Constitutional Theories, 89 YALE L.J. 1063 (1980).

38. See generally Levinson, supra note 20. For a more thorough treatment of the anti-democratic nature of the Court's intervention in Bush v. Gore, see AlAn M. DERSHOWITZ, SUPREME INJUSTICE: How THE High COURT HiJACKED THE Election (2001); see also HowARD GILlMAN, THE Votes That Counted: How the Court Decided the 2000 Presidential Election (2001). For a defense of the Court's decision, see Richard A. Posner, BREAKING THE DEADLOCK: THE 2000 Presidential Election, The Constitution, AND the Courts (2001).

39. 334 U.S. 1 (1948) (expanding the "state action" doctrine under the Fourteenth Amendment and ending the use of racially discriminatory private real estate contracts to maintain segregated neighborhoods).

40. 349 U.S. 294 (1955) (reversing the "separate-but-equal" doctrine and ending state segregation of public schools).

41. 369 U.S. 186 (1962) (enunciating the "one-person, one-vote" rule for federal electoral reapportionment).

42. 377 U.S. 533 (1964) (enunciating the "one-person, one-vote" rule for state electoral reapportionment). 
progressive reforms favored by the majority of Americans. In these cases the constitutional legislature was disunified-Congress and the presidency were controlled either by different political parties or by different wings of the same party - and Presidents used Justice Department litigation to invite judicial intervention and policy-making. ${ }^{43}$ In these circumstances it is far less clear why it would be inappropriate, or undemocratic, for courts to assume policy-making power even in areas where they may be institutionally less well-suited than the legislative branch. ${ }^{44}$

Focusing more attention on the demand-side of judicial policy-making also forces us to think differently about the Rehnquist Court's record and whether institutional reforms aimed at judicial independence are an appropriate remedy under current circumstances. As the contributions to this symposium make clear, the Rehnquist Court has been highly activist, both in substantive policymaking and in regulating the political-electoral process. From its decisions involving reapportionment, ${ }^{45}$ to its decisions involving federalism and congressional power ${ }^{46}$ to its stunning intervention in electoral politics in Bush v. Gore, ${ }^{47}$ the Rehnquist Court has demonstrated little reticence about entering the political thicket.

This recent activism fits nicely with the Ferejohnian model of judicialization of politics and the fact that during only two of the past fifteen years (1992 to 1994) has the Court faced a unified national government capable of restraining it through legislative overrides and strategic judicial selections. Yet, while it is clear that the Rehnquist Court has expanded the scope or space for judicial policy-making, it is less clear that it is any more independent from the elected branches than in the past. Indeed, only a few years ago the prevailing view expressed by legal academics, including Cass Sunstein in his 1996 forward to the Harvard Law Review's annual review of the Court, was that decision-making on the Rehnquist Court was best characterized as a form of "judicial minimalism" and "political pragmatism." ${ }^{48}$ Of course, this assessment was prior to Bush v. Gore, but even that decision should not lead us to alter our assessment of the institutional role of the Rehnquist Court.

Elsewhere, I have argued that the Rehnquist Court's decision-making has closely mirrored the centrist, sometimes incoherent and contradictory, political directions emanating from the elected branches over the past two decades of di-

43. I discuss the politics surrounding the Justice Department's intervention in these cases and the Court's political alliance with the executive branch in CLAYTON, POLITICS OF JUSTICE, supra note 22, at 127-37. See also Philip Elman, The Solicitor General's Office, Justice Frankfurter, and Civil Rights Litigation, 1946-1960: An Oral History, 100 HARV. L. REV. 817 (1987) (Interview with Norman Silber).

44. For other examples where the courts have been invited by one or both branches of the national government to make policy, see Graber, supra note 32.

45. See Hunt v. Cromartie, 532 U.S. 234 (2001); Bush v. Vera, 517 U.S. 952 (1996); Miller v. Johnson, 515 U.S. 900 (1995); Shaw v. Reno, 509 U.S. 630 (1993).

46. See Printz v. United States, 521 U.S. 898 (1997); United States v. Lopez, 514 U.S. 549 (1995);

New York v. United States, 505 U.S. 144 (1992).

47. 531 U.S. 98 (2000).

48. Cass R. Sunstein, Leaving Things Undecided, 110 HARV. L. REV. 4 (1996). 
vided government. ${ }^{49}$ Although a systematic analysis of the Court's record in this regard is beyond the scope of this essay, even a cursory review of the Rehnquist Court's most "activist" decisions is sufficient to demonstrate that its decisions remain squarely within the mainstream of contemporary political values and electoral preferences. The Court's decision in Bush v. Gore, for example, was a one-time, pragmatic intervention into an election where the difference between the parties and candidates was more stylistic than substantive. The election had resulted in a statistical dead heat, where at least half the country favored the outcome produced by the Court and even the losing candidate publicly accepted the legitimacy of the Court's decision. ${ }^{50}$ However troubling the decision was as a matter of "standard-form" legal analysis, ${ }^{51}$ it is difficult to see how the Court can be characterized as acting independently of democratic impulses or as untethered from the broader electoral currents of the national political system. The simple fact is that the election was so close that either outcome could be democratically justified. ${ }^{52}$

The policy substance of the Rehnquist Court's decisions in most other areas also has tended to track the general direction of the elected branches or democratic opinion more generally. The Court's decisions regarding abortion and welfare rights closely mirror actions by the elected branches and broader public opinion. $^{53}$ Its Equal Protection Clause decisions, whether in the context of affirmative action or legislative reapportionment, are largely in sync with majority views as expressed either in referendum elections, public opinion polls, or platform positions of the two major parties..$^{54}$ Its rulings in the areas of law enforcement authority and the rights of the accused echo the "war on drugs" and "get tough on crime" policies espoused by both major political parties and favored in opinion polls. ${ }^{55}$

Finally, it is not even clear that the Court's recent federalism decisions have thwarted democratic impulses at the national level. It is true that the Court's

49. See Cornell Clayton, Law, Politics, and the Rehnquist Court: Structural Influences on Supreme Court Decision-Making, in THE Supreme COURT In AMERICAN POLITICS: New Institutionalist INTERPRETATIONS 151 (Howard Gillman \& Cornell Clayton eds., 1999) [hereinafter Clayton, Structural Influences].

50. These factors may explain why public confidence in the Court has changed very little as a result of its decision in Bush v. Gore. See Herbert M. Kritzer, Into the Electoral Waters: The Impact of Bush v. Gore on Public Perceptions and Knowledge of the Supreme Court, 84 JUDICATURE (July-August 2001).

51. I agree with Professor Levinson that the Court's majority opinion was simply wrong as a matter of standard-form legal analysis. See Levinson, supra note 20, at 4. See also DERSHOWITZ, supra note 38; GILLMAN, supra note 38.

52. I do not mean to imply that democratic principles impose no obligation to ascertain which candidate captured the most votes in a close election, or that it is necessarily incumbent upon courts to resolve disputes in such elections. Rather, my point here is only that the election result in this case was so close, and so contested, that the outcome produced by the Court's intervention is not clearly an undemocratic one. See generally POSNER, supra note 38.

53. See Mark A. Graber, Rethinking Abortion: Equal Choice, the Constitution, And RePRodUCtIVE Politics (1996); Mark A. Graber, The Clintonification of American Law: Abortion, Welfare, and Liberal Constitutional Theory, 58 OHIO ST. L.J. 731 (1997).

54. Clayton, Structural Influences, supra note 49, at 164-76.

55. $I d$. 
decisions in this area have invalidated particular congressional policies-such as the Religious Freedom Restoration Act struck down in City of Boerne v. Flores $^{56}$ and the Violence Against Women Act invalidated in United States v. Morrison. ${ }^{57}$ Unlike the Court's federalism decisions in the early twentieth century that precipitated the constitutional crisis of the 1930s, however, the restraints imposed on federal regulatory activity by the Rehnquist Court thus far have been limited and peripheral. ${ }^{58}$ More to the point, the Court's general effort to readjust the balance of power between the federal and state governments is entirely consistent with politics at the national level. "New Federalism," the effort to devolve regulatory power and restore state authority, is a political idea adopted and fully operational in the elected branches of the national government at least two decades before the Court "rediscovered" the constitutional protections of state sovereignty in cases like New York v. United States, ${ }^{59}$ Pritz $v$. United States, ${ }^{60}$ and Lopez $v$. United States. ${ }^{61}$ New Federalism has been espoused by every President since Richard Nixon and was a cornerstone of the Republican recapture of Congress in the 1994 election. $^{62}$ Once again, whatever might be said about the Court's recent federalism decisions as exercises in standard legal analysis, their effect politically has been both modest and in line with trends in the elected branches. ${ }^{63}$

It is now possible to connect the normative discussion back to the earlier empirical point that courts rarely deviate far or for long from the political direction of the national governing coalition. Although it may be that the Supreme Court is an increasingly frequent and regular policy-maker as a result of electoral de-alignment and divided government, it is less clear whether the Court is any more autonomous from the elected branches than in the past. ${ }^{64}$ During periods of divided government, when the political direction of the constitutional legislature is less stable and coherent, it is difficult to know whether courts are acting independently or simply are acting more frequently. Yet much turns on this empirical question. If courts today are more frequent and consistent policy-

56. 521 U.S. 507 (1997).

57. 529 U.S. 598 (2000).

58. I discuss this in Clayton, Structural Influences, supra note 49, at 171-76.

59. 505 U.S. 144 (1992).

60. 521 U.S. 898 (1992).

61. 514 U.S. 549 (1995). For an excellent discussion of New Federalism as a political movement, see DAVID B. WALKER, THE REBIRTH OF FEDERALiSM (2000).

62. WALKER, supra note 61.

63. Indeed, the ebb and flow of state-federal political powers during the past fifty years may well demonstrate both why judicial supervision of federalism is unnecessary and the efficacy of what Herbert Wechsler termed the "political safeguards" of federalism. See Herbert S. Wechler, The Political Safeguards of Federalism: The Role of the States in the Composition and Selection of the National Government, 54 Colum. L. REv. 543 (1954). See also Garcia v. San Antonio Metro. Transit Auth., 469 U.S. 528 (1985).

64. The argument that courts cannot independently effect political and social change gains further empirical support in the very important book by GERALD N. ROSENBERG, THE HOLLOW HOPE: CAN COURTS BRING ABOUT Social CHANGE? (1991). 
makers, but are not more autonomous from democratic direction, then institutional reforms aimed at their independence will miss their intended purpose.

Even if we were convinced that divided control of the constitutional legislature has produced a more autonomous judiciary, however, it is unclear why changing the confirmation process and tenure of judges would be the best response. If divided government leads the court to take on this problematic role, why not attack the problem at its source? Institutional reforms aimed at strengthening political parties, reducing the incidence of split-ticket voting, and removing constitutional barriers to presidential-congressional cooperation (such as allowing for dual office holding) would strengthen the ability of the constitutional legislature to act coherently and decisively. Indeed, these types of reforms were suggested by the Committee on Constitutional Reform that was established in the 1980s to study the problems associated with prolonged divided government. ${ }^{65}$ Moreover, by encouraging stable, unified government, such reforms would raise the institutional costs to courts if they engaged in democratically undesirable forms of policy-making and would make the ordinary legislative process more effective in addressing major public policy concerns. This would reduce the level of judicial policy-making from both the supply-side and the demand-side by shifting democratic mobilizations back into the electoral arena.

IV

\section{Positive Modeling AND POLITICAL INFLUENCES IN JUDGING}

Whether the independence of judicial policy-making has increased under the current electoral-political regime in the United States, or just its scope and frequency, modeling judicial independence could provide a useful tool for understanding the role of courts in democracies more generally. Nevertheless, it is important to consider exactly what such a model would seek to explain and how its variables would be constructed and conceptualized. Similar positive political theory models-modeling court decisions as interdependent with congressional and presidential preferences-already exist. ${ }^{66}$ Although these models vary both in detail and in the number of dimensions or issues they include, they all begin with a simple assumption about judicial motivation: Judges are assumed to be rational, self-interested, policy-preference maximizers, and thus courts are assumed to push decisions as close to the "ideal" policy point as possible without

65. See A Bicentennial Analysis of the AmericAn Political Structure (1987). For a discussion of proposed reforms and the problems of divided government, see JAMES L. SUNDQUIST, CONSTITUTIONAL REFORM AND EFFECTIVE GOVERNMENT (1992).

66. See, e.g., Eskridge, Overriding Supreme Court Statutory Interpretation Decisions, supra note 3; Ferejohn \& Shipan, Congressional Influences on Bureaucracy, supra note 4; Rafael Gely \& Pablo T. Spiller, The Political Economy of Supreme Court Decisions: The Case of Roosevelt's Court-Packing Plan, 12 INT'L REV. L. \& ECON. 45 (1992); Rafael Gely \& Pablo T. Spiller, A Rational Choice Theory of the Supreme Court with Applications to the State Fair and Grove City Cases, 6 J. L. ECON. \& ORG. (1990); Brian A. Marks, A Model of Judicial Influence on Congressional Policymaking: Grove City College v. Bell 88-87 (Working Papers in Political Science, The Hoover Institute, Stanford University, 1988). 
getting overturned by the elected branches. ${ }^{67}$ One thing we know about these extant "separation-of-powers" models of judicial behavior, however, is that they have been spectacularly unsuccessful when subjected to empirical testing. ${ }^{6}$ In the words of Jeffrey Segal, who has published the most thorough empirical analysis of such models to date, "with (minor exceptions) systematic evidence in support (of these models) remains virtually non-existent."

The failure of positivist separation-of-powers models to explain actual judicial behavior may seem curious in light of the abundant empirical evidence that courts have historically followed the broader political direction of the national governing coalition. ${ }^{70}$ The contradiction, however, is found in the way such models conceptualize the relationship between politics and judging. By positing a singular judicial motivation (maximizing individual policy preferences), such models reduce institutional structures-constitutions, statutes, judicial doctrines-to mere shells within which judges act to accomplish their policy goals. The "law," and the professional norms associated with it, become mere instruments or barriers that judges must utilize strategically to advance their a priori political objectives. Thus, the relationship between the ideological values of the dominant governing coalition and individual judicial preferences are thus theorized as independent of each other and as strategic or unmediated by legal norms and institutions. Judges must consider the political values of the governing coalition only so as to avoid reprisals and overrides of their decisions. ${ }^{71}$ Such a view of judicial decision-making, however, underestimates the constitutive and normative power of institutions in shaping and ordering judicial preferences. The possibility that judges may shape their decisions on the basis of a normative understanding of the appropriate role of courts, or out of professional commitments to particular ways of thinking about the law and legal structures, is excluded by such models. ${ }^{72}$

This constricted conception of the role that legal and professional institutions have in shaping and constituting judicial motivations leads even Professor Ferejohn to recognize that existing positive theory models inaccurately portray

67. Eskridge, Overriding Supreme Court Statutory Interpretation Decisions, supra note 3; Ferejohn \& Shipan, Congressional Influences on Bureaucracy, supra note 4; Gely \& Spiller, A Rational Choice Theory, supra note 66; Gely \& Spiller, The Political Economy of Supreme Court Decisions, supra note 66; Marks, supra note 66.

68. See Jeffrey A. Segal, Separation-of-Powers Games in the Positive Theory of Congress and Courts, 91 AM. POL. SCI. REV. 28, 43 (1997).

69. Id. For a more general discussion of deeper theoretical and empirical failures of positive institutional theory, see DonAld P. GREen \& IAN SHAPIRO, PATHOLOGIES OF RATIONAL CHOICE Theory: A CRitique of ApPlications in Political SCIEnCE (1994). But see The Rational CHOICE CONTROVERSY: ECONOMIC MODELS OF POLITICS RECONSIDERED (Jeffrey Friedman ed., 1996).

70. See supra note 25 and accompanying text.

71. For a discussion of the theoretical assumptions embedded in such models, see Segal, supra note 61. For an excellent critique of these assumptions, see Howard Gillman, The Court as an Idea, Not a Building (or a Game): Interpretive Institutionalism and the Analysis of Supreme Court Decision-Making, in Supreme Court Decision-MAKing: New Institutionalist Approaches 65 (Cornell W. Clayton \& Howard Gillman eds., 1999).

72. See Gillman, supra note 71. 
the internal thought processes of judges. ${ }^{73}$ In addition, it is also why such models fail to garner empirical support for even the external explanatory value they promise. While it is clear that the dominant values and preferences in the political system shape judicial decision-making in important ways, that influence is rarely so direct and independent as positive theory approaches suggest. Rather, political values seep into judicial decision-making in less direct, but much more profoundly cognitive ways-ways that constitute judicial preferences themselves and form the basis for the normative understandings of law and legal structures that motivate judges. ${ }^{74}$

If this is the case, then one would expect to achieve very limited empirical success by modeling judicial decisions as dependent on the direct and immediate political or ideological values found in the elected branches. Rather, the influence of such values would be felt only as it was mediated by legal structures and institutions over time. Judges will reach decisions "in light of their own more or less coherent jurisprudential ideas about what the law requires." those ideas about the law will gradually be shaped by the values of the dominant governing coalition as they make their way into the processes of judicial selection, the mobilization of litigation resources, and the legal education proess.

Finally, a complete model of the nexus between judicial decision-making and control of the elected branches also will have to account for the interactive nature of this relationship. That is to say, the scope and independence of judicial policy-making is not just a result of divided control of the elected branches, but may also be one of its causes. I can only sketch out this point briefly here, but even a few examples will indicate how courts either can provoke or contravene electoral realignments by intervening in the political system. ${ }^{76}$ When the U.S. Supreme Court intervened in the slavery issue by rendering a decision in Dred Scott v. Sandford, ${ }^{77}$ or when it restricted government regulatory power during the early part of the twentieth century in cases such as Lochner $v$. New

73. Ferejohn, supra note 2, at 16:

I have little doubt that judges see themselves as deciding the cases before them in the light of their own more or less coherent jurisprudential ideas about what the law requires. But, from the perspective of the outside observer, their behavior is nonetheless predictable from a simple model of ideological voting.

Id. For a discussion of why such models fail to capture judging from an internal perspective, or as real, lived experiences, see Cornell W. Clayton, The Supreme Court and Political Jurisprudence: New and Old Institutionalisms, in SUPREME COURT DECISION-MAKING: NEW INSTITUTIONALIST APPROACHES 15 (Cornell W. Clayton \& Howard Gillman eds., 1999) [hereinafter Clayton, Institutionalism]. But see Lawrence Baum, THE PUZZLE OF JUdiCIAL BEHAVIOR (1997) (arguing that it is probably impossible to know with any empirical certainty about internal judicial motivations).

74. See Clayton, Institutionalism, supra note 73; Gillman, supra note 71.

75. Ferejohn, supra note 2.

76. For a more complete discussion of this point, see John B. Gates, The Supreme Court and Partisan Change: Contravening, Provoking, and Diffusing Partisan Conflict, in SUPREME COURT DECISIONMAKING: NEW InSTITUTIONALIST APPROACHES 98 (Cornell W. Clayton \& Howard Gillman eds., 1999).

77. 60 U.S. 393 (1856). 
York ${ }^{78}$ it provided important cleavage issues for ongoing electoral realignments. Subsequent to the Court's decisions, candidates and political parties_Lincoln's Republicans in the 1850s and Roosevelt's Democrats in the 1930s-attacked the Court and successfully used its decisions to build support for an alternative view of the American constitutional order. Conversely, in cases such as Roe $v$. Wade $^{79}$ and Regents of the University of California v. Bakke ${ }^{80}$ the Court's decisions may have kept potential cleavage issues from gaining traction within the electoral arena and thwarted electoral realignments. ${ }^{81}$ In either case, the role of courts relative to the degree of division within the electoral system ought to be thought of as both a dependent and an independent variable.

\section{$\mathrm{V}$}

\section{CONCLUSION}

Professor Ferejohn may have in mind ways to model both the positive (or strategic) and normative influences that institutions have on judicial behavior, as well as the interactive relationship between judicial decisions and divided control of the elected branches. ${ }^{82}$ But to do so will require abandoning some of the simplicity and parsimony of traditional positive theory (or strategic choice) models-and particularly the core, reductionist view that they hold of judicial motivation. This may, in turn, require paying more attention to the normative, not just the positive, institutional contexts of judicial decision-making and returning to a messy, but probably more realistic, view of judging as a human enterprise.

78. 198 U.S. 45 (1905).

79. 410 U.S. 113 (1973).

80. 438 U.S. 265 (1978).

81. See Gates, supra note 76.

82. For an example of an effort in this direction, see Cornell W. Clayton \& David May, A Political Regimes Approach to the Analysis of Legal Decisions, 32 POLITY 233 (2000). 